\title{
The two spotted spider mite, Tetranychus urticae (Acari: Tetranychidae), alternative prey for the lacewing Dichochrysa prasina (Neuroptera: Chrysopidae)
}

\author{
Maria L. PAPPAS ${ }^{1}$, Georgios D. BROUFAS ${ }^{2}$ and Dimitris S. KOVEOS ${ }^{1}$ \\ ${ }^{1}$ Aristotle University of Thessaloniki, Faculty of Agriculture, Laboratory of Applied Zoology and Parasitology, 54124 Thessaloniki, \\ Greece; e-mail: koveos@agro.auth.gr \\ ${ }^{2}$ Democritus University of Thrace, Department of Agricultural Development, Laboratory of Agricultural Entomology and Zoology,
} 68200 Orestiada, Greece

Key words. Chrysopidae, Dichochrysa prasina, Tetranychus urticae, temperature, alternative prey, lacewings

\begin{abstract}
The predatory lacewing Dichochrysa prasina Burmeister can feed and reproduce on various aphid species. However, other species such as the two spotted spider mite Tetranychus urticae Koch may serve as an alternative prey for this predator in the field in periods when the population density of aphids is low. In peach orchards in Northern Greece D. prasina larvae are often found during the summer months on leaves infested with $T$. urticae. The development and reproduction of $D$. prasina fed on $T$. urticae at a series of different constant temperatures were studied. The percentages of $D$. prasina larvae that completed their development when fed on T. urticae ranged from 12 to $60 \%$ depending on the temperature over the range from 20 to $30^{\circ} \mathrm{C}$, whereas at temperatures above $33^{\circ} \mathrm{C}$ no larvae survived. Longevity and egg production of $D$. prasina females fed during the larval stages on $T$. urticae were also determined and certain demographic parameters such as the intrinsic rate of increase $\left(r_{m}\right)$, mean generation time and net reproductive rate were estimated. Over the range of temperatures from 20 to $27^{\circ} \mathrm{C}$, the $r_{m}$ values were not significantly different and varied from 0.06629 to 0.07030 . Based on the results of the present study, the possible effect of the availability of $T$. urticae as prey for $D$. prasina during summer, when its main prey species is scarce, is discussed.
\end{abstract}

\section{INTRODUCTION}

The green lacewing Dichochrysa prasina Burmeister (Neuroptera: Chrysopidae) is a widespread aphid predator in the Palearctic, Oriental and African Regions (Séméria, 1984; Bozsik et al., 2002; Dong et al., 2004). In Europe, $D$. prasina is the second most abundant lacewing species after Chrysoperla carnea sensu lato (Canard et al., 2007). It is commonly found in warm and sunny places (Zelený, 1984), in orchards, field crops, vegetables and coniferous forests (Séméria, 1984). In Greece, D. prasina is recorded on the mainland and some islands in various agroecosystems such as arable crops, vegetables, fruit and olive orchards (Canard \& Laudého, 1977; Santas, 1984; Souliotis \& Broumas, 1994; Canard, 2001, 2003).

Adults of $D$. prasina mainly feed on honeydew and pollen grains (Bozsik, 1992, 2000) whereas larvae are generalist predators that feed on a variety of soft-bodied arthropods such as aphids, coccids, thrips, psyllids, mites and eggs of certain lepidopteran species (Principi, 1956; Babrikova, 1979; Santas, 1987; Pappas et al., 2007).

In commercial peach orchards in Northern Greece $D$. prasina is common from early May till late September, and during the summer months larvae of $D$. prasina are found on leaves infested with the two spotted spider mite Tetranychus urticae Koch (unpubl. data). During the summer months, when the prevailing high temperatures and arid conditions result in an abrupt population decline of the main aphid prey species Myzus persicae Sulzer (Pappas et al., 2007), T. urticae may act as an alternative prey for D. prasina. However, the high mid summer temperatures may also limit the survival and population increase of $D$. prasina. The aim of the current work was to study the suitability of T. urticae as an alternative prey of $D$. prasina over a range of temperatures similar to those occurring in the field during summer in Northern Greece. These results may be useful for understanding the possible effect the availability of $T$. urticae has on the survival, development and population dynamics of $D$. prasina during summer.

\section{MATERIAL AND METHODS}

\section{Predatory insects (D. prasina)}

For the experiments approximately 80 adult females and males of $D$. prasina were collected with a hand net from two peach orchards in the area of Alexandria (Northern Greece). The adults were maintained in pairs in plastic cages at $25 \pm 1{ }^{\circ} \mathrm{C}$ and at a photoperiod of $16 \mathrm{~L}: 8 \mathrm{D}$, with continuous access to water and a mixture of a liquid food (a volumetric mixture of protein hydrolysate (Sigma-Aldrich $\left.{ }^{\circledR}\right)$, honey, sugar and water, in ratio $1: 1: 1: 1)$ (Pappas et al., 2007). For the experiments, eggs laid by the above field collected females of $D$. prasina within the first five days following their transfer into laboratory conditions were used.

\section{Prey species (T. urticae)}

Individuals of the two spotted spider mite (T. urticae) were used as prey. They originated from a laboratory colony maintained for several years on detached bean leaves (Phaseolus vulgaris L.) at $25 \pm 1{ }^{\circ} \mathrm{C}$ and a photoperiod of $16 \mathrm{~L}: 8 \mathrm{D}$, as described by Veerman \& Koveos (1989). 


\section{Preimaginal survival and developmental time}

Eggs laid inside the cylindrical plastic cages over $12 \mathrm{~h}$ intervals by field collected females of $D$. prasina were individually transferred with the help of a fine hair camel brush into plastic Petri dishes $(5.5 \mathrm{~cm}$ in diameter) with a hole $(1.5 \mathrm{~cm}$ in diameter) in the lid covered by gauze, for ventilation. Subsequently, the dishes with the eggs were randomly allocated among six constant temperatures $\left(20,25,27,30,33\right.$ and $\left.35^{\circ} \mathrm{C}\right)$ and a photopheriod of $16 \mathrm{~L}: 8 \mathrm{D}$. For each temperature 50 eggs of $D$. prasina were used.

Upon hatching, the larvae were each provided with more than two hundred spider mites of various developmental stages every $12 \mathrm{~h}$ throughout their development and the developmental stage and survival recorded.

Two-way analysis of variance (ANOVA) was used to evaluate the effect of rearing temperature and sex (main factors) on total developmental time (SPSS, 2005). Since both factors significantly affected preimaginal development, further analysis of variance (ANOVA) for each developmental stage and sex was performed. Following a significant difference, means were compared by Student-Newman-Keuls test (SPSS, 2005). Prior to data analysis, the developmental time was logarithmically transformed and homogeneity of variances subsequently tested using Levene's test (SPSS, 2005). In those cases in which the data transformation failed to meet the requirements for parametric analysis, the nonparametric Kruskal-Wallis test was used and means were subsequently separated using the Mann-Whitney- $U$ test (SPSS, 2005). Percentages of individuals that completed preimaginal development (i.e. survived to the adult stage) at different constant temperatures were compared using a Chi-square test. The type-I error was corrected using the Bonferroni method (Sokal \& Rohlf, 1995).

\section{Adult longevity and fecundity}

Newly emerged females and males reared at each temperature were paired on the day of emergence and maintained in cylindrical plastic cages, where they had continuous access to water and the same liquid diet as fed to the field collected adults. Survival and the number of eggs laid were recorded daily for each individual female throughout its lifespan.

If any data transformation of either females' longevity or egg production failed to meet the requirements for parametric analysis, the nonparametric Kruskal-Wallis test was used (SPSS, 2005).

\section{Egg hatchability and progeny sex ratio}

Egg hatchability and progeny sex ratio of the lacewing individuals reared on $T$. urticae at each of the different temperatures was estimated as described by López-Arroyo et al. (1999). During the first week of the oviposition period, at all tested tem- peratures and for each ovipositing female, 30 eggs were randomly chosen and transferred individually to plastic Petri dishes. These eggs were incubated at the same temperature and photoperiodic conditions as the parental females. Daily, the eggs were inspected and the number of newly hatched larvae recorded. Arcsine transformation of data was used to equalize variances between treatments and an analysis of variance (ANOVA) performed to compare the effect of temperature on hatchability (SPSS, 2005).

Following egg hatch the effect of rearing temperature on offspring's sex ratio was determined by rearing 50 newly hatched larvae, selected at random, to the adult stage at each of the temperatures. The lacewing larvae were maintained at the same temperature and photoperiodic conditions as their parental females and provided daily with an ample supply of T. urticae. The adults that emerged at each temperature were counted and sexed. Sex ratios (i.e. number of females / number of females plus males) of the offspring at the different constant temperatures were determined and compared using a Chi-square test.

\section{Demographic parameters}

Life and fertility table parameters were estimated by combining data for preimaginal development, adult survival and reproduction at different constant temperatures, as described by Wang \& Tsai (2001). The intrinsic rates of population increase were estimated by iteratively solving the equation given by Birch (1948):

$$
\sum_{x-0}^{n} e^{-r x} l_{x} m_{x}=1
$$

where $x$ is the mean age class, $m_{x}$ the mean number of female progeny per female of age $x$ and $l_{x}$ the probability of survival to age $x\left(l_{x}\right)$. The Jacknife procedure was used to estimate a standard error for the $r_{m}$ values at different temperatures (Meyer et al., 1986). The $r_{m}$ values were further compared using StudentNewman-Keuls test (Sokal \& Rohlf, 1995) as described by Broufas \& Koveos (2001). Furthermore, for each rearing temperature the demographic parameters: net reproductive rate $\left(\mathrm{R}_{0}\right.$ $=\Sigma l_{x} m_{x}$, number of female offspring produced per female), mean generation time $\left(\mathrm{T}=\ln \mathrm{R}_{0} / r_{m}\right)$ and finite rate for increase $\left(\lambda=e^{r m}\right.$, number of times the population will multiply itself per unit of time) were estimated (Birch, 1948; Southwood, 1978).

\section{RESULTS}

\section{Preimaginal survival and developmental time}

Rearing temperature significantly affected the percentage of individuals that completed their preimaginal development $\left(\chi^{2}=25.26\right.$, df $\left.=3, P<0.05\right)$ (Table 1). At the highest temperatures of 33 and $35^{\circ} \mathrm{C}$, all lacewing larvae failed to complete their preimaginal development

TABLE 1. Preimaginal survival (\%) of $D$. prasina reared on $T$. urticae at six constant temperatures.

\begin{tabular}{|c|c|c|c|c|c|c|c|c|}
\hline \multirow{2}{*}{$\begin{array}{c}\text { Rearing } \\
\text { temperature } \\
\left({ }^{\circ} \mathrm{C}\right)\end{array}$} & \multicolumn{7}{|c|}{ Number $\left(\mathrm{n}_{\mathrm{i}}\right) /$ percentage $\left(\mathrm{a}_{\mathrm{i}} \%\right)$ of individuals surviving to each developmental stage } & \multirow{2}{*}{$\begin{array}{c}\text { Total } \\
\text { preimaginal } \\
\text { survival (\%) }\end{array}$} \\
\hline & $\mathrm{n}^{1}$ & L1 & L2 & L3 & Prepupa & Pupa & Adults & \\
\hline 20 & 50 & $48 /(96 \%)^{2}$ & $34 /(68 \%)$ & $29 /(58 \%)$ & $22 /(44 \%)$ & $21 /(42 \%)$ & $20 /(40 \%)$ & $40 a^{3}$ \\
\hline 25 & 50 & $47 /(94 \%)$ & $41 /(82 \%)$ & $40 /(80 \%)$ & $33 /(66 \%)$ & $33 /(66 \%)$ & $30 /(60 \%)$ & $60 \mathrm{~b}$ \\
\hline 27 & 50 & 47 / (94\%) & $42 /(84 \%)$ & $42 /(84 \%)$ & $34 /(68 \%)$ & $32 /(64 \%)$ & $17 /(34 \%)$ & $34 \mathrm{a}$ \\
\hline 30 & 50 & 47 / (94\%) & $35 /(70 \%)$ & $32 /(64 \%)$ & $19 /(38 \%)$ & $13 /(26 \%)$ & $6 /(12 \%)$ & $12 \mathrm{c}$ \\
\hline 33 & 50 & 45 / (90\%) & $37 /(74 \%)$ & $33 /(66 \%)$ & $4 /(8 \%)$ & $0 /(0 \%)$ & $0 /(0 \%)$ & 0 \\
\hline 35 & 50 & 44 / (88\%) & $22 /(44 \%)$ & $3 /(6 \%)$ & $0 /(0 \%)$ & $0 /(0 \%)$ & $0 /(0 \%)$ & 0 \\
\hline
\end{tabular}

${ }^{1}$ Number of eggs of $D$. prasina reared at each temperature; ${ }^{2} \mathrm{a}_{\mathrm{i}}=100 \times\left(\mathrm{n}_{\mathrm{i}} / \mathrm{n}\right) \% ; \mathrm{n}=50 ;{ }^{3}$ Percentages followed by the same latter are not significantly different $\left(\chi^{2}\right.$-test, $\left.P>0.05\right)$. 
TABle 2. Mean developmental time ( \pm SE) (days) of preimaginal stages of D. prasina reared on $T$. urticae at different constant temperatures and $16 \mathrm{~L}: 8 \mathrm{D}$.

\begin{tabular}{ccccccccc}
\hline Temperature $\left({ }^{\circ} \mathrm{C}\right)$ & $\mathrm{n}^{1}$ & Egg & L1 & L2 & L3 & Prepupa & Pupa & Egg-Adult \\
\hline Females & & & & & & & & \\
20 & 9 & $7.2 \pm 0.2 \mathrm{a}^{2}$ & $10.7 \pm 0.6 \mathrm{a}$ & $11.1 \pm 1.0 \mathrm{a}$ & $21.1 \pm 0.9 \mathrm{a}$ & $10.1 \pm 0.5 \mathrm{a}$ & $9.7 \pm 0.5 \mathrm{a}$ & $69.9 \pm 2.1 \mathrm{aA}{ }^{3}$ \\
25 & 16 & $5.9 \pm 0.2 \mathrm{~b}$ & $8.3 \pm 0.3 \mathrm{~b}$ & $7.6 \pm 0.3 \mathrm{~b}$ & $12.2 \pm 0.8 \mathrm{~b}$ & $8.0 \pm 0.4 \mathrm{~b}$ & $6.9 \pm 0.5 \mathrm{~b}$ & $48.8 \pm 1.1 \mathrm{bA}$ \\
27 & 8 & $4.4 \pm 0.2 \mathrm{c}$ & $8.0 \pm 0.7 \mathrm{~b}$ & $6.4 \pm 0.2 \mathrm{c}$ & $10.6 \pm 0.4 \mathrm{~b}$ & $3.0 \pm 0.3 \mathrm{c}$ & $8.1 \pm 0.5 \mathrm{ab}$ & $40.5 \pm 0.8 \mathrm{cA}$ \\
$30^{* *}$ & 4 & $3.7 \pm 0.5$ & $5.7 \pm 0.5$ & $4.2 \pm 0.2$ & $7.2 \pm 0.5$ & $2.3 \pm 0.3$ & $4.3 \pm 0.3$ & $27.2 \pm 0.2$ \\
Males & & & & & & & & \\
20 & 11 & $6.9 \pm 0.2 \mathrm{a}$ & $10.7 \pm 0.6 \mathrm{a}$ & $10.1 \pm 0.7 \mathrm{a}$ & $19.3 \pm 1.0 \mathrm{a}$ & $10.2 \pm 0.4 \mathrm{a}$ & $8.5 \pm 0.4 \mathrm{a}$ & $65.7 \pm 1.2 \mathrm{aA}$ \\
25 & 14 & $5.9 \pm 0.2 \mathrm{~b}$ & $7.8 \pm 0.4 \mathrm{~b}$ & $8.0 \pm 0.5 \mathrm{~b}$ & $9.2 \pm 0.5 \mathrm{~b}$ & $8.4 \pm 0.5 \mathrm{~b}$ & $6.0 \pm 0.6 \mathrm{~b}$ & $45.3 \pm 0.7 \mathrm{bB}$ \\
27 & 9 & $4.7 \pm 0.2 \mathrm{c}$ & $7.7 \pm 0.4 \mathrm{~b}$ & $5.7 \pm 0.5 \mathrm{c}$ & $8.9 \pm 0.7 \mathrm{~b}$ & $3.6 \pm 0.3 \mathrm{c}$ & $6.9 \pm 0.3 \mathrm{ab}$ & $37.7 \pm 0.8 \mathrm{cA}$ \\
$30^{* *}$ & 2 & $3.5 \pm 0.5$ & $5.5 \pm 0.5$ & $4.5 \pm 0.5$ & $6.5 \pm 0.5$ & $2.5 \pm 0.5$ & $4.5 \pm 0.5$ & $26.5 \pm 2.5$ \\
\hline
\end{tabular}

${ }^{1}$ Number of individuals surviving to the adult stage; ${ }^{2}$ Means within a column followed by the same lower case letter are not significantly different (Student-Newman-Keuls test, $P>0.05$ ); ${ }^{3}$ Mean developmental times of females and males at the same temperature followed by the same upper case letter are not significantly different (t- test, $P>0.05$ ); ${ }^{* *}$ Due to the low number of individuals surviving this treatment was excluded from the analysis.

and were not included in the data analysis (Table 1). The survival from egg to adult emergence varied from 34 to $40 \%$, and was not significantly different at 20 and $27^{\circ} \mathrm{C}$ $\left(\chi^{2}=0.169, \mathrm{df}=1, P>0.05\right)$. The highest percentage of immature survival $(60 \%)$ was at $25^{\circ} \mathrm{C}\left(4<\chi^{2}<25.1\right.$, df $=$ $1, P<0.05)$, and the lowest $(12 \%)$ at $30^{\circ} \mathrm{C}\left(6.85<\chi^{2}<\right.$ $25.1, \mathrm{df}=1, P<0.05)$.

Further data analysis revealed that temperature significantly affected the developmental rate of the lacewing larvae. Two-way analysis of variance showed that both rearing temperature $(F=291.53$, df $=2,61, P<0.001)$ and sex $(F=14.49$, df $=1,61, P<0.001)$ significantly affected the total preimaginal development time of $D$. prasina, but that the interaction between these two factors was not significant $(F=0.057, \mathrm{df}=2,61, P=0.944)$.

As shown in Table 2, temperature significantly affected the duration of the preimaginal developmental stages of $D$. prasina of both females $(6.629<F<67.175$, df $=2$, $30, P<0.05)$ and males $(8.301<F<51.057$, $\mathrm{df}=2,31$, $P<0.05)$. Furthermore, a gradual and significant decrease in mean total preimaginal developmental time for females $(F=102.251$, df $=2,30, P<0.005)$ and males $(F=224.782$, df $=2,31, P<0.05)$ was recorded with the increase in temperature over the range from 20 to $30^{\circ} \mathrm{C}$ (Table 2). Males completed their preimaginal development in a significantly shorter period than females at $25^{\circ} \mathrm{C}(t=2.659, \mathrm{df}=28, P<0.05)$. However, there was no significant difference in the mean total preimaginal developmental times of males and females at $20^{\circ} \mathrm{C}(t=$ $1.831, \mathrm{df}=18, P=0.084)$ and $27^{\circ} \mathrm{C}(t=1.831, \mathrm{df}=15, P$ $=0.084)$.

\section{Adult longevity and fecundity}

As shown in Table 3, with increase in the rearing temperature from 20 to $27^{\circ} \mathrm{C}$ there was a substantial reduction in the mean total egg production from approximately 151 to 98.8 eggs per female. However, this was not statistically significant $\left(\chi^{2}=3.451\right.$, df $\left.=2, P=0.178\right)$. Similarly, the increase in rearing temperature from 20 to $27^{\circ} \mathrm{C}$ resulted in a substantial though not statistically significant $\left(\chi^{2}=4.623, \mathrm{df}=2, P=0.099\right)$ reduction (approximately 14 days) in mean adult longevity.

However, at $30^{\circ} \mathrm{C}$ females of $D$. prasina lived on average approximately 6 days and did not lay any eggs. It is, therefore, concluded that $30^{\circ} \mathrm{C}$ is close to the upper temperature limit for survival and reproduction in $D$. prasina (Table 3$)$.

The age-specific oviposition rates and survival of $D$. prasina at different temperatures are shown in Fig. 1. According to these results the maximum daily oviposition rates varied from approximately 5 eggs/ female at $20^{\circ} \mathrm{C}$ to 9.8 eggs/ female at $27^{\circ} \mathrm{C}$. Furthermore, maximum lifespan

TABLE 3. Mean total egg production (eggs / female) $( \pm \mathrm{SE})$, mean female adult longevity (days) $( \pm \mathrm{SE})$, egg hatchability $(\%)$ and progeny sex ratio of $D$. prasina fed on $T$. urticae at different constant temperatures and $16 \mathrm{~L}: 8 \mathrm{D}$.

\begin{tabular}{cccccc}
\hline Temperature & $\mathrm{n}^{1}$ & $\begin{array}{c}\text { Mean total egg production } \\
(\text { eggs / female) }\end{array}$ & $\begin{array}{c}\text { Longevity } \\
(\text { mean lifespan in days) })^{3}\end{array}$ & Egg hatchability (\%) $)^{4}$ & Progeny sex ratio $^{5}$ \\
\hline $20^{\circ} \mathrm{C}$ & $9(2)^{2}$ & $151.1 \pm 38.8 \mathrm{a}$ & $46.4 \pm 7.5 \mathrm{a}$ & $77.1 \pm 2.5 \mathrm{a}$ & 0.53 \\
$25^{\circ} \mathrm{C}$ & $16(0)$ & $150.8 \pm 15.2 \mathrm{a}$ & $44.0 \pm 3.3 \mathrm{a}$ & $80.4 \pm 2.1 \mathrm{a}$ & 0.46 \\
$27^{\circ} \mathrm{C}$ & $8(1)$ & $98.8 \pm 22.1 \mathrm{a}$ & $32.3 \pm 2.3 \mathrm{a}$ & $81.9 \pm 2.8 \mathrm{a}$ & 0.55 \\
$30^{\circ} \mathrm{C}$ & $4 *(4)$ & $0.0 \pm 0.0$ & $6.0 \pm 0.4$ & - & - \\
\hline
\end{tabular}

${ }^{1}$ Number of individuals tested; ${ }^{2}$ Number of individuals that did not lay eggs; ${ }^{3}$ Means within a column followed by the same letter are not significantly different (Nonparametric Kruskal-Wallis); ${ }^{4}$ Means within a column followed by the same letter are not significantly different (Student-Newman-Keuls test, $P>0.05$ ); ${ }^{5}$ Sex ratio $=$ females / females + males; $*$ Due to the low number of individuals surviving this treatment was excluded from the analysis. 

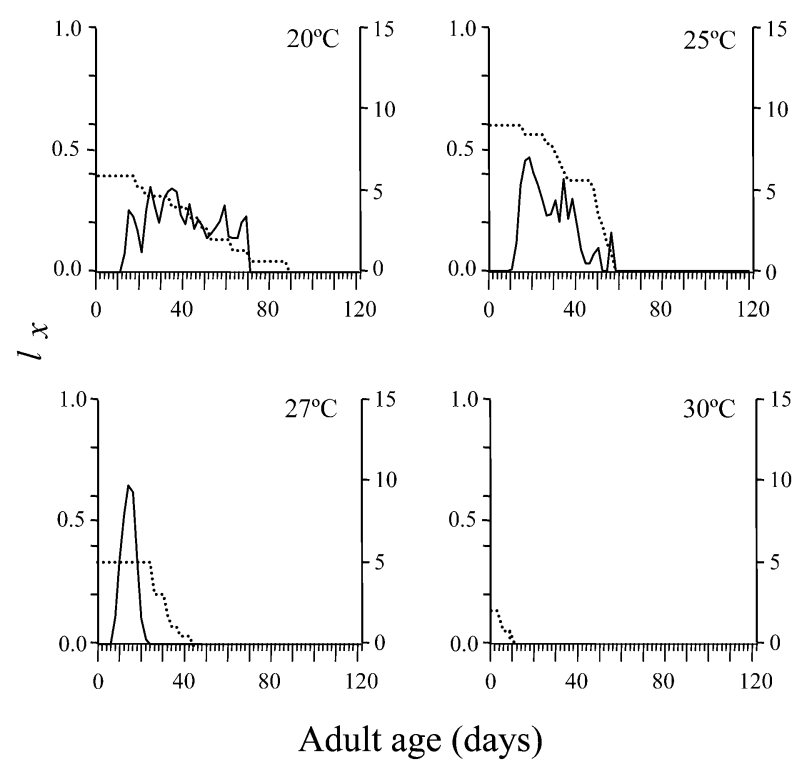

Fig. 1. Age-specific oviposition rates $\left(m_{x}\right.$, mean number of eggs laid per day per female) (solid line) and survival $\left(l_{x}\right)$ (dotted line) of D. prasina females reared on T. urticae at different constant temperatures and a photoperiod of $16 \mathrm{~L}: 8 \mathrm{D}$.

gradually declined from approximately $90 \mathrm{~d}$ at $20^{\circ} \mathrm{C}$ to 50 and $42 \mathrm{~d}$ at 25 and $27^{\circ} \mathrm{C}$, respectively, whereas at the high temperature of $30^{\circ} \mathrm{C}$ the adults lived on average 6 days.

\section{Egg hatchability and progeny sex ratio}

The temperatures at which the parental generation were reared did not significantly affect egg hatchability $(F=$ $0.718, \mathrm{df}=2,27, P=0.497)$, which was high and ranged from 77.1 to $81.9 \%$. Furthermore, the sex ratios of the offspring produced at the different temperatures did not differ significantly $\left(\chi^{2}=0.381, \mathrm{df}=2, P>0.05\right)$ and ranged from 0.46 to 0.55 (Table 3 ).

\section{Demographic parameters}

Further data analysis was used to estimate the demographic parameters (i.e. intrinsic rate of increase, net reproductive rate, mean generation time and finite rate of increase) of $D$. prasina at different temperatures (Table 4). The estimated values of the mean generation time at the different temperatures varied from approximately 47 to 73 days. Temperature substantially affected the estimated values of net reproductive rate $\left(R_{0}\right)$, which increased from approximately 26 female offspring/ female at $20^{\circ} \mathrm{C}$ to 42.5 female offspring/ female at $25^{\circ} \mathrm{C}$. At higher temperatures there was an abrupt decline in the $\mathrm{R}_{0}$ value. The highest $r_{m}$ value was recorded at $27^{\circ} \mathrm{C}$. The estimated $r_{m}$ values were similar over the range of temperatures from 20 to $27^{\circ} \mathrm{C}$ and varied from 0.06629 at $20^{\circ} \mathrm{C}$ to 0.07030 at $27^{\circ} \mathrm{C}$ (Table 4 ).

\section{DISCUSSION}

Temperature has a significant effect on the development, longevity and reproduction of chrysopid species. In several chrysopid species, such as Mallada desjardinsi (Navas), Chrysoperla nipponensis (Okamoto) (Nakahira et al., 2005) and Chrysopodes lineafrons Adams \& Penny (Silva et al., 2007), reared on Ephestia kuehniella (Zeller) eggs, as well as for three Ceraeochrysa species (C. cincta (Schneider), C. smithi (Navàs) and C. cubana (Hagen) reared on Sitotroga cerealella (Olivier) eggs and Acyrthosiphon pisum Harris (López-Arroyo et al., 1999), high temperatures (from 28.5 to $30^{\circ} \mathrm{C}$ ) retard preimaginal development and result in an increased larval mortality (Canard \& Volkovich, 2001). Our results show that a low percentage of $D$. prasina larvae completed their development at $30^{\circ} \mathrm{C}$ and none at $33^{\circ} \mathrm{C}$. The optimum temperature for development and reproduction in D. prasina is $27^{\circ} \mathrm{C}$. When D. prasina is reared on E. kuehniella eggs or Myzus persicae (Sulzer) nymphs, survival and egg production at $30^{\circ} \mathrm{C}$ are much higher than in the present study, which indicates that prey quality may affect development a high temperatures (Pappas et al., 2008, Pappas et al., unpubl.).

Apart from temperature other factors such as the nutritional quality or availability of prey may also significantly affect the developmental parameters and population dynamics of chrysopids under field conditions (Canard \& Principi, 1984). In the case of D. prasina, T. urticae is a prey of lower nutritional quality compared to certain aphid species such as M. persicae and Hyalopterus pruni (Geoffroy) (Pappas et al., 2007). According to Şengonca et al. (1987), for another chrysopid, namely C. carnea, $T$. urticae is also the least appropriate prey when compared to other prey species such as the eggs of Mamestra brassicae (L.) and the aphids M. persicae, Aphis fabae Scopoli and Brevicorne brassicae (L.). C. carnea larvae need to consume more than 12000 eggs of T. urticae in order to complete their development (Şengonca \& Coeppicus

TABLE 4. Life table statistics of D. prasina reared on T. urticae at different constant temperatures and 16L : 8D.

\begin{tabular}{cccccccc}
\hline Temperature & $\mathrm{n}^{1}$ & $\mathrm{r}_{\mathrm{m}}$ & \multicolumn{2}{c}{$95 \% \mathrm{CI}^{2}$} & $\mathrm{R}_{0}$ & $\mathrm{~T}$ & $\lambda$ \\
\hline $20^{\circ} \mathrm{C}$ & 7 & $0.06629 \mathrm{~b}$ & 0.05694 & 0.07562 & 26.8 & 71.1 & 1.069 \\
$25^{\circ} \mathrm{C}$ & 16 & $0.06683 \mathrm{~b}$ & 0.06431 & 0.06934 & 42.5 & 73.1 & 1.069 \\
$27^{\circ} \mathrm{C}$ & 7 & $0.07030 \mathrm{~b}$ & 0.06040 & 0.00198 & 14.6 & 47.0 & 1.073 \\
$30^{\circ} \mathrm{C}$ & - & - & - & - & - & - & \\
$33^{\circ} \mathrm{C}$ & - & - & - & - & - & - & \\
$35^{\circ} \mathrm{C}$ & - & - & - & - & - & - & \\
\hline
\end{tabular}

\footnotetext{
${ }^{1}$ Number of individuals tested; $\mathrm{r}_{\mathrm{m}}$ values within each temperature followed by the same letter are not significantly different at $P=$ 0.05 using the Student-Newman-Keuls test; ${ }^{2} 95 \%$ confidence intervals; $r_{m}=$ intrinsic rate of natural increase $\left(\mathrm{d}^{-1}\right)$; $\mathrm{R}_{0}=$ net reproductive rate (female offspring per female); $\mathrm{T}=$ mean generation time $(\mathrm{d}) ; \lambda=$ finite capacity for increase $\left(\mathrm{d}^{-1}\right)$.
} 
1985). Thus, in mid summer in the absence of more suitable prey (aphids) the presence of T. urticae may favour the survival and development of $D$. prasina. Other studies have shown that in apple and peach orchards during summer certain spider mite species such as Panonychus ulmi Koch, T. urticae and Bryobia arborea Morgan and Anderson may serve as alternative food for certain chrysopids such as Chrysoperla carnea (Stephens), Chrysoperla rufilabris (Burmeister) and Chrysopa oculata Say (Szentkirályi, 2001 and references therein).

The estimated values of the intrinsic rate of increase $\left(r_{m}\right)$ for D. prasina fed on T. urticae ranged from 0.06629 at $20^{\circ} \mathrm{C}$ to 0.07030 at $27^{\circ} \mathrm{C}$. Even though these values are substantially lower than those reported when $D$. prasina is fed on aphids (Pappas et al., 2007) they indicate that $D$. prasina populations reared on $T$. urticae may increase at temperatures from $20^{\circ} \mathrm{C}$ to $27^{\circ} \mathrm{C}$. Furthermore, these values for $D$. prasina fed on $T$. urticae are substantially higher than those reported for Chrysopa perla (L.) reared on different aphid species, which ranged from 0.0015 to 0.0227 at $20^{\circ} \mathrm{C}$ (Canard, 1970). Therefore, we may assume that in northern Greece the population increase of $D$. prasina may be more limited by high ambient field temperatures than the availability of prey.

In conclusion, our results show that $D$. prasina may successfully complete its development and reproduce over a wide range of temperatures when reared on $T$. urticae. However, temperatures of or higher than $30^{\circ} \mathrm{C}$ may adversely affect both the survival and reproduction of $D$. prasina. In peach orchards during summer, increasing temperatures and low relative humidity result in a gradual decline in aphid and increase in T. urticae populations. Therefore, T. urticae could serve as a nutritionally sufficient alternative food for larvae of $D$. prasina during summer. In addition, the population decline of $D$. prasina during summer may be more due to high summer temperatures than availability of prey. Our experiments were done at constant temperatures. However, fluctuating field temperatures may significantly affect life history traits of insects and eventually their intrinsic rate of increase and population dynamics (Davis et al., 2006). Thus, further experiments are required in order to evaluate the importance of $T$. urticae as an alternative food for D. prasina during summer at fluctuating temperatures.

\section{REFERENCES}

BABRIKova T. 1979: Bioecological studies on the green deer fly (Chrysopa prasina Burmeister). Gradin. Lozar. Nauka 16: 12-18 [in Bulgarian].

BIRCH L.C. 1948: The intrinsic rate of natural increase of an insect population. J. Anim. Ecol. 17: 15-26.

Bozsik A. 1992: Natural adult food of some important Chrysopa species (Planipennia: Chrysopidae). Acta Phytopathol. Entomol. Hung. 27: 141-146.

BozsIK A. 2000: Nahrungsanalytische Untersuchungen an einigen mitteleuropäischen Chrysopiden-Imagines (Neuroptera: Chrysopidae). Beitr. Entomol. 50: 237-246.

Bozsik Á., Mignon J. \& Gaspar C. 2002: The green lacewings of Belgium (Neuroptera: Chrysopidae). Acta Zool. Hung. 48: $53-59$.
Broufas G.D. \& Koveos D.S. 2001: Development, survival and reproduction of Euseius finlandicus (Acari: Phytoseiidae) at different constant temperatures. Exp. Appl. Acarol. 25: 441-460.

CANARD M. 1970: Incidences de la valeur alimentaire de divers pucerons (Homoptera, Aphididae) sur le potentiel de multiplication de Chrysopa perla (L.) (Neuroptera, Chrysopidae). Ann. Zool. Écol. Anim. 2: 345-355.

CANARD M. 2001: Présence en Grèce continentale de Chrysoperla carnea (Stephens, 1836) sensu stricto (Neuropt., Chrysopidae). Bull. Soc. Entomol. Fr. 106: 416.

CANARD M. 2003: Chrysoperla mutata (McLachlan, 1898), une espèce nouvelle pour la Crète et l'île de Chios, Grèce (Neuropt., Chrysopidae). Bull. Soc. Entomol. Fr. 108: 216.

CANARD M. \& LAUDÉHO Y. 1977: Les névroptères capturés au piège de McPhail dans les oliviers en Grèce. 1: L'Île d'Aguistri. Biol. Gallo-Hellen. 7: 65-75.

CAnard M. \& Volkovich T.A. 2001: Outlines of lacewing development. In McEwen P.K., New T.R. \& Whittington A.E. (eds): Lacewings in the Crop Environment. Cambridge University Press, Cambridge, pp. 130-153.

CANARD M. \& PrinciPI M.M. 1984: Development of Chrysopidae. In Canard M., Séméria Y. \& New T.R. (eds): Biology of Chrysopidae. Dr. W. Junk, The Hague, pp. 57-75.

CAnARD M., Letardi A. \& Thierry D. 2007: The rare Chrysopidae (Neuroptera) of southwestern Europe. Acta Oecol. 31: 290-298.

Davis J.A., Radcliffe E.B. \& Ragsdale D.W. 2006: Effects of high and fluctuating temperatures on Myzus persicae (Hemiptera: Aphididae). Environ. Entomol. 35: 1461-1468.

Dong K.Z., Li W.-Z., Cui J.-Z. \& Yang X.-K. 2004: Three new species of Dichochrysa (Insecta: Neuroptera: Chrysopidae) from China, with a checklist of Chinese Dichochrysa. Raffles Bull. Zool. 52: 67-74.

López-Arroyo J.I., Tauber C.A. \& Tauber M.J. 1999: Comparative life histories of the predators Ceraeochrysa cincta, C. cubana, and C. smithi (Neuroptera: Chrysopidae). Ann. Entomol. Soc. Am. 92: 208-216.

Meyer J.S., Ingersoll C.G., McDonald L.L. \& Boyce M.S. 1986: Estimating uncertainty in population growth rates: jacknife vs bootstrap techniques. Ecology 67: 1156-1166.

Nakahira K., Nakahara R. \& Arakawa R. 2005: Effect of temperature on development, survival, and adult body size of two green lacewings, Mallada desjardinsi and Chrysoperla nipponensis (Neuroptera: Chrysopidae). App. Entomol. Zool. 40: 615-620.

Pappas M.L., Broufas G.D. \& Koveos D.S. 2007: Effects of various prey species on development, survival and reproduction of the predatory lacewing Dichochrysa prasina (Neuroptera: Chrysopidae). Biol. Control 43: 163-170.

Pappas M.L., Broufas G.D. \& Koveos D.S. 2008: Effect of temperature on survival, development and reproduction of the predatory lacewing Dichochrysa prasina (Neuroptera: Chrysopidae) reared on Ephestia kuehniella eggs (Lepidoptera: Pyralidae). Biol. Control 45: 396-403.

PrINCIPI M.M. 1956: Contributi allo studio dei "Neurotteri" italiani XIII. Studio morphologico, etologico e sistematico di un gruppo omogeneo di specie del gen. Chrysopa Leach (C. flavifrons Brauer, prasina Burm. e clathrata Sch.). Boll. Ist. Entomol. Univ. Bologna 21: 319-410.

SAnTas L.A. 1984: On some Chrysopidae of Greece. In Gepp J., Aspöck H. \& Hölzel H. (eds): Progress in World's Neuropterology. Proceedings of the 1st International Symposium on Neuropterology (22-26 September 1980, Graz, Austria). 
Osterreichischen Akademie der Wissenschaften, Graz, pp. 167-172.

SANTAS L.A. 1987: The predators' complex of pear-feeding psyllids in unsprayed wild pear trees in Greece. BioControl 32: $291-297$.

SÉMÉRIA Y. 1984: Savannah: mediterranean climates. In Canard M., Séméria Y. \& New T.R. (eds): Biology of Chrysopidae. Dr. W. Junk Publishers, The Hague, pp. 167-180.

ŞEngonca Ç. \& CoeppICus S. 1985: Frassaktivität von Chrysoperla carnea (Stephens) gegenüber Tetranychus urticae. $Z$. Ang. Entomol. 72: 335-342.

Şengonca Ç., Gerlach S. \& Melzer G. 1987: Einfluss der Ernährung mit unterschiedlicher Beute auf Chrysoperla carnea (Stephens) (Neuroptera: Chrysopidae). Z. Pflanzenkr. Pflanzensch. 94: 197-205.

Silva P.S., Albuquerque G.S., Tauber C.A. \& Tauber M.J. 2007: Life history of a widespread Neotropical predator, Chrysopodes (Chrysopodes) lineafrons (Neuroptera: Chrysopidae). Biol. Control 41: 33-41.

SOKAL R.R. \& Rohlf F.J. 1995: Biometry: The Principles and Practice of Statistics in Biological Research. 3rd ed. Freeman and Company, New York, 887 pp.

Souliotis K. \& Broumas T. 1994: Population dynamics of predatory Chrysopidae in vegetable crops in the area of Mara- thonas Attika. In Tsitsipis J.A., Kapatos E.T. \& Koutroubas A.G. (eds): Proceedings of the 4th Greek Entomological Congress (14-17 October 1991, Volos, Greece). pp. 65-72 [in Greek].

Southwood T.R.E. 1978: Ecological Methods. 2nd ed. Chapman \& Hall, London, $592 \mathrm{pp}$.

SPSS 2005: SPSS Base 12.0 for Windows. User's Guide. Chicago, IL.

SZENTKIRÁLYI F. 2001: Lacewings in fruit and nut crops. In McEwen P.K., New T.R. \& Whittington A.E. (eds): Lacewings in the Crop Environment. Cambridge University Press, Cambridge, pp. 172-238.

Veerman A. \& Koveos D.S. 1989: Separation of photoperiodic and circadian effects on the termination of diapause in the spider mite Tetranychus urticae. Experientia 45: 1143-1146.

WANG J.J. \& TSAI J.H. 2001: Development and functional response of Coelophora inaequalis (Coleoptera: Coccinellidae) feeding on brown citrus aphid, Toxoptera citricida (Homoptera: Aphididae). Agr. Forest Entomol. 3: 65-69.

ZelenÝ J. 1984: Chrysopid occurrence in west palearctic temperate forests and derived biotopes. In Canard M., Séméria Y. $\&$ New T.R. (eds): Biology of Chrysopidae. Dr. W. Junk Publishers, The Hague, pp. 151-160.

Received September 18, 2007; revised and accepted February 26, 2008 